\title{
Uexküllian Planmässigkeit
}

\author{
Jesper Hoffmeyer \\ Institute of Molecular Biology, University of Copenhagen \\ Sølvgade 83, DK-1307 Copenhagen, Denmark \\ e-mail: hoffmeyer@mermaid.molbio.ku.dk
}

\begin{abstract}
In strict opposition to the prevailing positivist conception of nature as senseless and deprived of meaning Jakob von Uexküll claimed that a certain planmässigkeit was operative in nature. This idea however might be taken to mean that organic evolution is not itself a creative process but a gradual, if majestic, unfolding of Nature's own master plan. Such an idea would threaten to restore determinism in the center of biological theory, and this would seriously contradict the vision of biosemiotics shared by most of its proponents. It lies at the heart of biosemiotics and of Peircean cosmological philosophy that indeterminacy is primary, that "habit taking" or interpretation are real processes in the world, and therefore that belief in the law of necessity is unfounded. It is suggested that Uexküllian planmässigkeit is in fact reconcilable with a modern non-deterministic understanding. In a certain sense the Umwelten of animals have indeed developed in accordance to a natural planmässigkeit, but this is a plan that incessantly traps life in certain strategic choices and in the same time diversifies the dimensionality of options for dealing with these choices, i. e. "the adjacent possible" in the terms of Stuart Kauffman.
\end{abstract}

\section{The problem of Planmässigkeit}

The opening in Hamburg of Jakob von Uexküll-Archiv für Umweltforschung und Biosemiotik is one of those rare instances where foresight and retrospection meets while both are still in need of each other. Jakob von Uexküll's pioneering contribution to the study of life, his Umweltlehre, is still in need of clarification, and at the same time the biosemiotic reframing of biological theory, which owes so much to his 
work, has only recently taken its first serious steps and can still be fruitfully informed by the work of the pioneer. To create an institutional framework for this kind of meeting place between historical writings and emerging new agendas in science is the principal purpose for an archive, and seen in this light the establishment of the Jakob von Uexküll archive in Hamburg in 2004 is timely indeed.

As is always the case when an institution like this is opened there are some risks to consider: Will the veneration one feels for the pioneer tend to bias critical enquiry? Will the modern perspective, in this case biosemiotics, tend to bias our evaluation of work done nearly a hundred years ago? And will the "Uexküllian" perspective, which the archive is supposed to throw on biosemiotics, tend to blind us from such areas in the field where a modern approach may require a paradigmatic distance from the old master? To counter such risks head-on from the beginning is clearly essential for the intellectual success of this new initiative.

I am not in a position to discuss these risks here, and I shall focus my discussion on only one particular aspect of von Uexküll's work, which to a biochemist like myself, trained in the very Anglo-Saxon tradition of contemporary molecular biology, is likely to provoke some discomfort. This aspect may shortly be labeled through a concept upon which Jakob von Uexküll himself put very much emphasis, the concept of Planmässigkeit.

In the introduction to the English-language version of Streifzüge durch die Umwelten von Tieren und Menschen, Thure von Uexküll tells us that his father, Jakob von Uexküll, saw mind "as an organ created by nature to perceive nature" (T. v. Uexküll 1992b: 281). And further:

Nature may be compared to a composer who listens to his own construction. This results in a strangely reciprocal relationship between nature, which has created man, and man, who not only in his art and science, but also in his experiential universe, has created nature. (T. v. Uexküll 1992b: 281)

In the preface to this same volume of Semiotica, which he himself guest edited, Thure von Uexküll accentuates the point even further:

In Jakob von Uexküll's view the task of biology is the examination of Planmässigkeit in nature, which means the examination of the composition of systems and of the sign processes which produce and maintain them. For the positivistic understanding of Science in his time, speaking of Planmässigkeit 
in nature meant inhibiting research. In von Uexküll's view, however, research had to begin with the proposition that Planmässigkeit could be an aspect of nature, for the presupposition that nature is meaningless and senseless is itself a metaphysical presupposition. (T. v. Uexküll 1992a: 277).

Now here comes my discomfort: the institution of such a plan inherent to nature might be interpreted as meaning that organic evolution is not itself a creative process but a gradual, if majestic, unfolding of Nature's own master plan, i.e. evolution would not figure as a real historical process in the sense that something happened through evolution which was not already determined beforehand. The idea of such a plan thus in a strange way restores determinism to the center of biological theory. Or to state it differently, in such a universe a wise demon might indeed tell fortunes in the cards. This however would seriously conflict with the vision of biosemiotics that I think most of its proponents share. For it lies at the heart of biosemiotics and of Peircean cosmological philosophy that indeterminacy is primary, that "habit taking" or interpretation are real processes in the world, and therefore that belief in the law of necessity is unfounded.

It is therefore a matter of great importance to analyze the nature of the teleological principle that Jakob von Uexküll invoked in his work. The automatism by which positivistic science quite automatically shies away from any suggestion of final causation in nature is indeed very unsatisfactory because it leaves such a heavy burden of explanation on efficient causation as sole legitimate agency in the world. Not surprisingly several theoretical biologists recently called for an eventual return to a richer notion of causality in biology (Rosen 1991; Salthe 1993; Riedl 1997; Ulanowicz 1997). Mainstream biologists, however, consider the teleological nature of living entities and the processes they engage in to be only an "as if" teleology or what they call teleonomy. In Darwinian explanations for the purposeful nature of adaptive traits one does of course make reference to the consequences of those traits for fitness, but, as has often been remarked, the consequences that explain the existence of adaptive traits are the consequences those traits have had; they are not the consequences that they will have or can have. And since the consequences precede the effects, no violation of the general scheme of efficient causation is implied.

In a sharp analysis of the debates on teleology in Darwinian explanations the philosopher T. L. Short has nevertheless recently claimed 
that 'Darwin's use of 'final cause' accords with the Aristotelian idea of final causes as explanatory types - as opposed to mechanical causes, which are always particulars" (Short 2002: 323). Buried in this subtle formulation lies the presupposition that final causation, as the concept was originally conceived by Aristotle, is different from the "externalist" or vitalistic kinds of teleology which were ultimately implied rather by Plato's idea of a divine craftsman who creates things intentionally to satisfy the ends of his own.

Aristotelian teleology, by contrast, is "internal" or "immanent". An organism's ends are not given to it by an external agent. It is that of the organism itself, but not in the vitalistic sense that there is an agency within the organism that holds this end in some sort of quasi-conscious intention. The end is "internal" to the organism because it is the organism's form. (Short 2002: 325-326)

It is also worth realizing that contrary to modern conceptions of final causation Aristotelian final causation does not imply simple human purposes such as desires or wants. In fact the desire, e.g. the desire to be healthy, is not the real final cause behind a person's acts, e.g. that he takes long walks. Rather, in this case, the desire to stay healthy is an efficient cause that not only precedes but also brings about the act of walking. What needs be explained is the reason for the concrete desire, and this reason, Aristotle says, is the general attractiveness of health: "It is health itself, as a general type of possible outcome, which explains - by its attractiveness, hence, as a final cause - one's desire for it" (Short 2002: 327).

Essentially, then, final causes, as Aristotle conceived them, are types of outcomes. As such they are potentialities, whether or not actualized, as for instance an acorn, whose 'destination' it is to grow into an oak, not into a birch or a salamander - but which, as is well known, most often doesn't grow at all. Furthermore, as types of outcome Aristotelian final causes are never particulars - in the future or in the past - and thus the term "backward causation" has nothing to do with final causes.

Based on this understanding of Aristotelian teleology Short can clarify his claim on Darwinian explanation in the following way:

What I am suggesting is that we take seriously the currently popular talk of "selecting for" a property or type of trait (Sober 1984). Taking it seriously means accepting that talk at its face value: it describes evolutionary processes as shaped by types of outcome and it explains outcomes by citing the types 
those outcomes exemplify. But a type of outcome that explains its own exemplification is what translators of Aristotle have named a "final cause", as Darwin appears to have recognized. (Short 2002: 337)

Short's conclusion may come as a surprise to many scientist who have thought that Darwinian natural selection was the ultimate assurance against any supposed need for teleology in science. On the other hand it explains the otherwise quite contra-intuitive claim that purposive behavior would somehow ensue if only chance mutations and "blind" selective force worked long enough upon non-purposive systems. Natural selection is not blind, it searches types of outcomes, or in biosemiotic terms:

Chance mutations are not selected because they are beneficial; they are beneficial because they happen to appear in a relational system which was already well prepared for them. That blind selection should be the sole cause of evolution is one of the mightiest fictions of our time. Selection is never blind; it is always guided by the prior formation of developmental and semiotic integration. (Hoffmeyer 2001b: 393)

Louis Pasteur put it very clearly in his famous: "Chance favors only the prepared mind".

Teleology then does not in itself contradict a scientific understanding of the world or of evolution and biosemiotics is in fact deeply dependent on the acceptance of that kind of final causation which Charles Peirce described in the following terms

[...] we must understand by final causation that mode of bringing facts about according to which a general description of result is made to come about, quite irrespective of any compulsion for it to come about in this or that particular way; although the means may be adapted to the end. The general result may be brought about at one time in one way, and at another time in another way. Final causation does not determine in what particular way it is to be brought about, but only that the result shall have a certain general character. (CP 1.121)

Contrast this to Peirce's conception of efficient causation:

Efficient causation, on the other hand, is a compulsion determined by a particular condition of things, and is a compulsion acting to make that situation to begin to change in a perfectly determinate way; and what the general character of the result will be in no way concerns efficient causation. (CP 1.121) 
Natural laws operate like final causes when they are used as explanatory tools. As Lucia Santaella-Braga has explained, quoting Peirce:

A law is something general and for that reason, it is not a force. 'For force is compulsion; and compulsion is hic et nunc. It is either that or it is no compulsion. Law, without force to carry it out, would be a court without a sheriff; and all its dicta would be vaporings'. Thus the relation of law, as a cause, to the action of force, as its effect, is final, or ideal, causation, not efficient causation (CP 1. 213). [...] Final without efficient causation is helpless, but efficient without final causation is worse than helpless, 'by far, it is mere chaos; and chaos is not even so much as chaos, without final causation; it is blank nothing' (CP 1. 200). (Santaella Braga 1999: 502)

Semiosis, or sign action, is always embedded in sensible material processes and for that reason has a dynamic side, that allows the communicative process to run, as well as a complimentary or mediating side. The first of these sides is governed by the compulsive force of efficient causation, the second expresses the controlling agency of final causation.

Much confusion in these matters stems from the lack of understanding of this intimate interplay between efficient and final causation. For example, as Short points out, a vital force is not, no matter how mysterious and goal-directed it is, a final cause; it is an efficient cause: "it is not itself a goal. It is not a type of outcome. It is a particular force that already exists" (Short 2002: 328). Thus the taboo against final causation has worked its way into our tacit thought patterns to such an extent that even the adversaries of scientific mechanicism, tried to counter it by reducing final causation to an efficient causative agency, a vital force. No wonder, then, that this attempt ended in ridicule. This however doesn't solve the problems which so disturbed the minds of the vitalists and of Jakob von Uexküll. In retrospect we may perhaps better see that the failure of thinkers such as Driesch and Bergson was due, at least to a large extent, to the fact, that thermodynamics was still at their time limited by the nearequilibrium perspective, which was transcended by Ilya Prigogine only much later (Prigogine 1980). When these thinkers made their contribution to natural philosophy the second law of thermodynamics might well be understood as an implicit finality inherent in our universe, but the perspective was still that of an irreversible and destructive dynamic. The interpretation of the second law as a fundamentally constructive power and the alliance of this power with emergentist ideas based in non-linear dynamics and complexity theory had not yet any chance of being 
proposed (Brooks et al. 1989; Kauffman 1993; 1995; Salthe 1993; Depew, Weber 1995; Weber 1998). The sense of telos in nature had hardly any legitimate Lebensraum in science unless it disclosed itself in anti-Darwinian clothes. A contemporary reading of Jakob von Uexküll's work should be aware of this state of affairs.

There is of course a tension in Uexküll's writings between harmony and freedom. The more nature's composition is described as harmonious, the less freedom can be ascribed to it, for how could a perfect world be free to change - unless for the worse? A nature that listens to its own composition is not a metaphor that easily mingles with the idea of a deteriorating harmony. The contrapuntal duets, Uexküll's famous vision of a Goethean reciprocity, such that the beetle is pea-like and the pea is beetle-like, tends, as Frederik Stjernfelt observes, to make the whole of nature fuse with meanings in such a way that all Umwelten marvelously fit each other locally. But Stjernfelt also points to a solution of this dilemma:

While the naturalized subjectivism tends to make it impossible to see beyond the horizon of the Umwelt, the musical metaphor makes possible an inference to mend this problem. [...] The melody - arch-example for the Gestalt theorists from von Ehrenfels, Stumpf, and the early Husserl onwards to the Berlin and Graz schools - articulates an organized structure disconnected from the here-and-now of physics and implying a teleological circle foreseeing the last note already by the intonation of the first. Thus - as Merleau-Ponty remarks [Merleau-Ponty 1995: 233] — this metaphor makes it possible to see the life of the individual organism as a realization, a variation of the theme, requiring no outside vitalist goal - a variation, we may add, which constitutes the condition of possibility of the modification of the animal's system of functional circles and hence the acquiring of new habits, possibly to govern evolutionary selection in Baldwinian evolution. [...] Music may be perfect, but it is far from always the case. (Stjernfelt 2001: 87-88)

Interpreting Uexküll's work in this way, we can see that Planmässigkeit does not imply a deterministic unfolding of a preordained order, and although the telos involved in Planmässigkeit is of course very different from Peirce's vision of evolutionary cosmology, it is not necessarily antagonistic, either to Peirce or to modern day biosemiotic understanding. ${ }^{1}$

See also chapter 10 in Sebeok 1979. 


\section{"Goal" and "plan" in Uexküll's biology}

Let us now proceed to consider more concretely how "plan" and "goal" is connected in Jakob von Uexküll's biology. The example of different species of night moths reacting to audible danger signals is illuminating (Uexküll 1992). According to Uexküll all night moths respond to alarming sounds with a species specific reaction pattern. Species that are easily visible because of their light coloring invariably fly away upon perceiving a high tone, whereas species that have protective coloration alight in response to the same tone. The same sensory cue has the opposite effect, and Uexküll comments:

It is striking how the two opposite kinds of action are governed by a plan. There can be no question of discrimination or purposiveness, since no moth or butterfly has ever seen the color of its own skin. The plan revealed in this instance appears even more admirable when we learn that the artful microscopic structure of the night moth's hearing organ exists solely for this one high tone of the bat. To all else, these moths are totally deaf. (Uexküll 1992: $352-353)$

Even more instructive perhaps are the examples he gives from experiments on the behavior of grasshoppers and crickets (Fig. 1; Uexküll 1992: 353-354).

A female grasshopper is placed under a glass bell before a microphone. When the grasshopper fiddles, the sounds will be transmitted to a loudspeaker just outside the glass bell, which is thick enough to stop any fiddling sounds getting through. When grasshoppers of the opposite sex are placed outside the glass bell these grasshoppers, as the experiment shows, direct their attention only to the loudspeaker, ignoring the grasshopper which can be seen fiddling in vain inside the bell. The partners make no advances whatsoever, the optical image being ineffectual.

As Uexküll explains, in this case:

[...] a specific receptor cue initiates a functional cycle, but, since the normal object is eliminated, the proper effector cue, which would be necessary to extinguish the first perceptual cue, is not produced. Normally, another receptor cue should intervene at this point and activate the next functional cycle. The nature of this second receptor cue must be investigated more closely [...]. In any event, it is a necessary link in the chain of functional cycles which lead to mating. (Uexküll 1992: 354) 


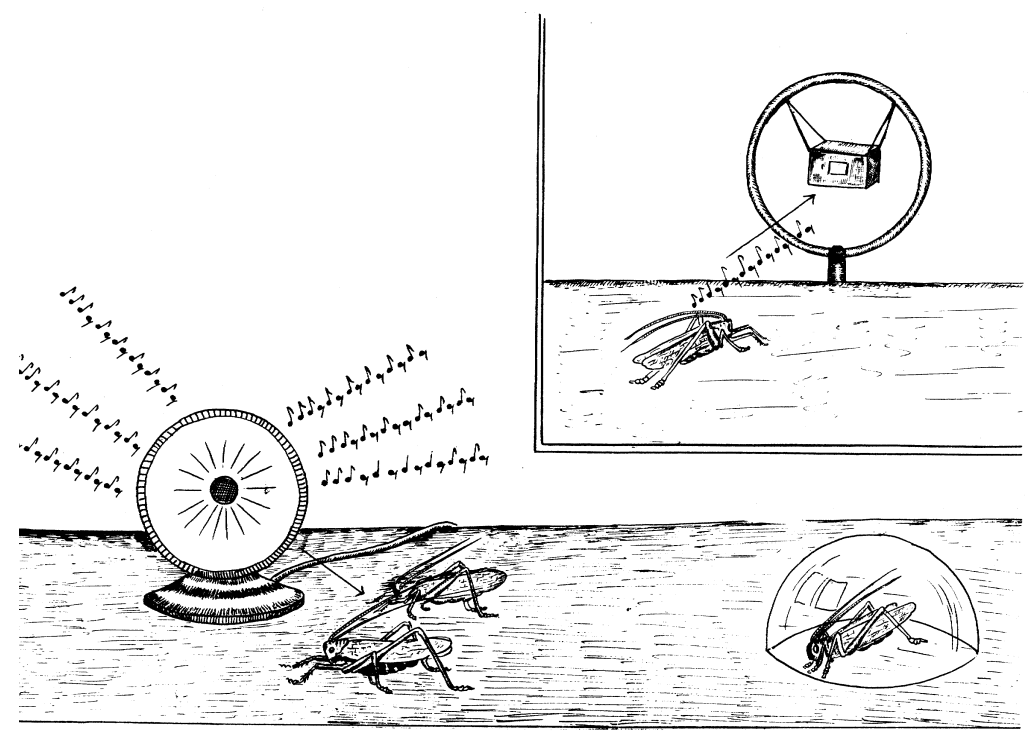

Figure 1. Grasshoppers in front of a loudspeaker (from Uexküll 1992: 353).

So, Uexküll explicitly rejects the notion of a goal to describe the behavior of these animals and instead prefers talking about a "coordination of the manifestations of animals" under the viewpoint of a plan. He does, however, admit that "perhaps later certain actions of the highest mammals may prove to be teleological actions, which in turn are dovetailed into the over-all plan of nature" (Uexküll 1992: 352).

However, in rejecting individual goals and also rejecting natural selection, one would indeed like to know how this plan of nature could actually be brought about at all, and how it manages to sustain itself. One might think that organisms would be able somehow to learn to do things they didn't do before, to acquire new habits or changed systems of functional cycles, but to the modern mind the why question, e.g. why would the animal learn this or that, does indeed seem to be in need of an answer. Or differently stated, the plan or final cause must have means at its disposal, efficient causalities. What are these? Where are they to be found?

I would submit that maybe Uexküll's sharp rejection of any goal directed behavior in animals may hide a possible answer to this 
question. For illustration let me briefly dwell on an example which the German embryologist Hans Spemann once claimed was the direct cause for his life long occupation with embryology, the case of Siamese twins in salamanders. Hamburger (1988) tells the story in The Heritage of Experimental Embryology, and I quote from there. The young Spemann working with salamander embryos conducted an experiment in which he constricted an egg without separating the blastomeres completely. ${ }^{2}$ He thereby obtained a strange animal with two heads, one trunk and one tail (Fig. 2). Much later (in 1943) he explained the importance he ascribed to this one experiment:

Such animals came to the stage of feeding and it was now most remarkable to see how once the one head and at another time the other caught a small crustacean, how then the food moved through the separate foreguts to the joint posterior intestine [...]. It was probably irrelevant for the well-being of the strange double creature which head had caught the food; it was of benefit to the whole. Nevertheless, one head pushed the other away with its fore legs. Hence two egotisms in the place of one, called forth by the spatial separation of the anlagen. (Spemann 1943; quoted in Hamburger 1988)

Normally this "egotism" of an animal is taken for granted and it doesn't strike us as odd at all. But the case of an animal possessing two opposed "egotisms" immediately shows us how much in need of an explanation this property is. By the very failure to serve its ordinary purpose in these poor creatures, we are directed to the question what agency brings about "egotism" in normal organisms. What does this agency consist of? How could it be created in the first place? It is easy enough to say that organisms without an "egotism" would disappear because they would be expected to be outcompeted by organisms possessing this peculiar property, and that may indeed explain why "egotism" has survived once it happened to come about. But it doesn't explain what it is or how it works, and accordingly it doesn't account for the question of how it appeared - out of nowhere, i.e. out of non-egotistic systems? Must not Spemann's "egotism" be pushed backwards in time to the very first organisms on earth? Could there have been life-forms without this "egotism"?

2 I am grateful to Scott F. Gilbert for directing my attention to Hamburger's book for a comment on Spemann's work on Siamese twins in salamanders. 


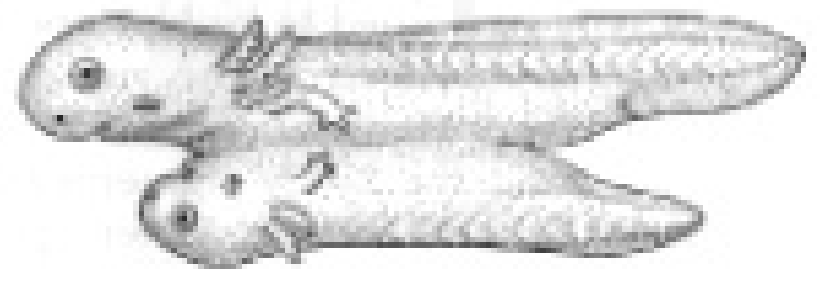

Figure 2. Siamese twins in salamanders.

But if this is so - and I find it hard to see how one could deny it then Spemannian "egotism" is an irreducible holistic property of life as such, for clearly "egotism" doesn't make any sense at levels below the whole organism. Thus to the extent single tissues or cells in multicellular organisms also posses a kind of "egotism", which as a matter of fact they do (Buss 1987), then the higher level "organismic egotism" must normally be capable of inducing its objectives upon the lower level units (cancer and birth are well known exceptions where a lower level "egotism", i.e. the interests of single tumor cells or the of foetal system respectively, win over the holistic "egotism").

Now, the question is: what is the relation between Spemannian egotism and an individual goal? If the term goal is understood to refer to the conscious kinds of purposes to which we as human beings are so accustomed, then of course a goal is a very different thing from Spemann's egotism, but taken in a broader sense goals might be seen as far more widespread in nature. Even the chemotactic behavior of a bacterium swimming upstream in a gradient of nutrients reflects the holistic interest of the bacterial system in getting as much nutrient molecules as the receptor capacity allows for. Is not this interest a goal? All living systems have insides, or else are organized in such a way that somehow they produce activities aimed at sensing, catching, fleeing from, mating with ... something outside the system (Hoffmeyer 1998; 2000; 2001a). In each case biochemistry or physiology may eventually fully explain the efficient causalities involved in these activities - as has for instance largely been done for bacterial chemotaxis - but this does not catch the holistic dimension: why is the 
system organized to carry out such a holistic intentionality, or "aboutness"?

To answer this question modern biology invariably invokes natural selection. Countless minute changes along thousands and even millions of generations gradually tuned all proteins in the whole organism to work as one integrated seemingly intentional system for the sake of survival efficiency. As already noted this hardly explains the appearance of "egotism" in the first place, but it does of course give an important - though in this author's view by no means full explanation for the concrete elaboration of the holistic intentionality acquired by each separate case of species.

We are thus not opposed to the idea that the efficient causality, the force, so to say, that brings about evolutionary change to a large extent may be accounted for in terms of selective processes acting upon the reproductive efforts of populations situated in a restricted space of solutions. But from a biosemiotic point of view this selection force is itself blind and only gets direction through the semiotic potential inherent to living systems. Organisms need their environments, and since these environments mostly consist of other organisms, an elaborate intra- as well as interspecific semiotic dynamic is established from the very beginning of life around organismic needs. Only because of this semiotic dynamic does the evolutionary process have direction and creativity. Explaining the holistic intentionality of organisms thus requires an historical account of the situatedness of the organism in question in the holistic semiotic dynamics to which it belongs. Holistic intentionality cannot just be explained reductively through an account of the selective tunings of myriad biochemical processes characteristic for the efficient operation of the individual self-interest considered in isolation from its biosemiotic historical roots.

And this is finally what brings us to von Uexküll's Planmässigkeit. Individual organisms, grasshoppers, bacteria or human beings, do in fact have goals in the sense just outlined, but these goals are irreducibly bound to the whole biosemiotic setting. And as we shall see in the following paragraphs this biosemiotic setting of nature's individual species is itself a product of endless diversifications of holistic patterns. 


\section{Diversification as plan}

I remember how as a young student of biochemistry I wondered why it is that textbooks always equated oxidative processes with exergonic or energy harnessing processes, whereas reductive process were always equated to endergonic or energy consumptive processes. The core of the matter is, of course, that oxidative processes are also always reductive processes, one component becoming oxidized at the same time as another component is reduced. In the paradigmatic case of animal respiration the oxidative process consumes oxygen that ends up as carbon dioxide, i.e. 2 atoms of oxygen $(\mathrm{O})$ bound to one atom of carbon $(\mathrm{C})$, but at the same time oxygen itself becomes reduced in that it goes from free oxygen in the air to chemically bound oxygen in carbon dioxide. This last aspect of the process, the reduction part of it, is always tacitly presupposed but is rarely explicitly mentioned, and thus tends to become forgotten by naive students.

At the other end of life, the photosynthetic activity of plants consists of a reduction of carbon dioxide to carbohydrate. As is well known, this process depends on the ability of the green plants to take up energy from solar radiation and use it for splitting water into oxygen and hydrogen in such a way that oxygen is set free to the atmosphere whereas hydrogen is used for reducing carbon dioxide to carbohydrates and all the other organic molecules making up plant material.

It was not until I saw how photosynthesis and respiration fitted into each other, that I realized the true character of this grand process, which is in fact the essence of biospheric chemistry on earth: see Fig. 3. Seen from above, what takes place in the biosphere is nothing but the diversifications of the grand scheme, whereby solar energy drives the splitting of water into hydrogen and oxygen, whereas animals reunify these two constituents through the food chains, making sure that every bit of energy obtainable in the process is used up. As if one might be tempted to say - the whole trick of animate nature is to disturb water so that oxygen and hydrogen are separated from each other, thereby introducing a kind of "longing" between them that drives the two atoms forward through their complicated pathways, leading in due time to an extinction of the longing through a reassembling of the disturbed water molecule. 


Plant life:
$6 \mathrm{H}_{2} \mathrm{O}+6 \mathrm{CO}_{2}==>\mathrm{C}_{6} \mathrm{H}_{12} \mathrm{O}_{6}+6 \mathrm{O}_{2}$
PHOTOSYNTHESIS

\begin{tabular}{c} 
Animal life: \\
$6 \mathrm{O}_{2}+\mathrm{C}_{6} \mathrm{H}_{12} \mathrm{O}_{6}=\Rightarrow 6 \mathrm{CO}_{2}+6 \mathrm{H}_{2} \mathrm{O}$ \\
RESPIRATION \\
\hline
\end{tabular}

\begin{tabular}{cc|} 
Life \\
$\mathrm{H}_{2} \mathrm{O}==>$ & $2 \mathrm{H}+\mathrm{O}==>\mathrm{H}_{2} \mathrm{O}$ \\
SUM
\end{tabular}

Figure 3. When the processes of respiration (A) and photosynthesis (B) are summed the diversity of biochemistry disappears under the overall process which simply consists in the molecular splitting and reassembling of water (C).

In Stuart Kauffman's recent book "Investigations", an important part of the analysis turns on the question of the non-ergodicity of the universe, meaning that the universe never had the time it would have needed should its present state of affairs in any way be representative of its inbuilt possibilities (Kauffman 2000). The persistent movement of the universe into the "adjacent possible" precludes its ever reaching a state that depends on statistical likelihood. In stead the universe is historical, for "history enters when the space of the possible that might have been explored is larger, or vastly larger, than what has actually occurred" (Kauffman 2000: 152). And as Kauffman points out:

Even if we consider the universe as a whole, at the levels of molecular and organizational complexity of proteins and up, the universe is kinetically trapped. It has gotten where it has gotten from wherever it started, by whatever process or flow into a persistently expanding possible, but cannot have gotten everywhere, The ergodic hypothesis fails us here on any relevant timescale. More, the biosphere, and the universe as a whole, may well be 
kinetically trapped into an evermore astonishingly small region of the entire space of the possible it might have reached. Stated otherwise, the set of actual small molecules and large molecules such as proteins that do exist now is presumably an increasingly tiny subvolume of the total set that might have arisen by now in the biosphere or the universe since the big bang. (Kauffman 2000: 145)

Perhaps somewhat paradoxically, then, the diversification of entities and processes occurring in the universe necessarily, according to Kauffman's analysis, goes hand in hand with an increasing load of lost opportunities, things that might have happened, structures that might have been formed but did not in fact happen or form. The point of the matter is that both of these trends, the trend toward increased diversity and the trend toward lost opportunities, are of an increasing dimensionality. It is probably the most bold conjecture in Kauffman's book, a conjecture he argues persuasively for, that "our biosphere and any biosphere expands the dimensionality of its adjacent possible, on average, as rapidly as it can" (Kauffman 2000: 151). Kauffman is well aware, that this "burgeoning order of the universe" cannot be reduced to matter alone, to entropy (or the negation of entropy for that matter), to information, or to anything that simple. The propagation of organization and the subsequent growing diversification of the world is taken care of by autonomous agents and these agents are semiotic creatures. An autonomous agent may be defined quite rigorously according to Kauffman as an "autocatalytic system able to reproduce and able to perform one or more thermodynamic work cycles", and in earlier work he has shown how such agents will be expected to selforganize given the kind of world our Earth system belongs to (Kauffman 1993). But, as explained in the present book, Kauffman is acutely aware that this definition leads to more intractable questions of "measuring" or "recognition". For, if work is defined as "the constrained release of energy", where will the constraints come from? At least it will take work to produce them, and this is not all:

Autonomous agents also do often detect and measure and record displacements of external systems from equilibrium that can be used to extract work, then do extract work, propagating work and constraint construction, from their environment. (Kauffman 2000: 110) 
And this definitely brings us to the core of biosemiotics, and also poses the question of the origin of life in a new way which shall not, however, be further explored here (Neumann 1966; Pattee 1977; Hoffmeyer, Emmeche 1991; Hoffmeyer 1998; 2000; 2001a).

Returning to the discussion of water it should now be admitted that photosynthetic water splitting was not at all the original source of energy flow through biotic systems. Fermentation and redox processes involving inorganic materials, as well as photosynthetic processes departing from nitrogenous or ferrochemical compounds, considerably preceded the appearance of water splitting in the biosphere. The summative harmony indicated in figure 3 between photosynthesis and respiration also only established itself several billions of years after the origin of life, when sufficient stores of oxygen had been built up in the atmospheric system. This reflects the fact that photosynthetic water splitting, as well as the respiratory utilization of free oxygen, are both hard jobs to tackle from a biochemical point of view, and autonomous agents capable of carrying them out were not among the simplest kinds of autonomous agents to be invented. But, as we know, the problems were eventually solved and the successive diversification of the biosphere gradually came to reflect the efficiency of this particular energy flow scheme.

Whether the water splitting scheme may be said to represent the best available choice for a biotic energy flow scheme on earth, I do not know and it is probably not easy to know. Most biochemists would perhaps think that it was, but, as we all know, unexpected possibilities may often hold surprises. The question may not however be especially relevant to the biosphere anymore since a quite new dimension of the "adjacent possibles" were eventually realized in the middle of the animal kingdom, a dimension which slowly unfolded its potentials for hundreds of millions of years and has now with the human species finally expanded the range of energy sources available to living systems far beyond anything known before. We might call this dimension the neurosemiotic dimension of life. The whole work of von Uexküll focused on aspects of this dimension.

We can summarize the discussion so far by noting that the Umwelten of animals certainly have developed in accordance to a plan of nature, a plan that all the time traps life in certain strategic choices and at the same time diversifies the dimensionality of ways to deal with these choices. The Danes, having been trapped by historical 
incident to a shrinking nation (from a territorial point of view that is) have developed a dictum which strangely catches this aspect of evolution: "what is externally lost, shall be internally gained" said the Danes (to the extent that the educational system in Denmark was considerably strengthened as a strategy inside this perspective, it actually did work well for a century or more). What goes on in the biosphere seems to accord very much with this same fundamental principle: having lost a large majority of the options originally available for the evolutionary path, diversification nevertheless has expanded the field of future options by inventing radically new and sophisticated life strategies based on highly developed semiotic competences - not least, we shall claim, the strategy of experienced Umwelten - and this is why the biosphere has increasingly become a semiosphere (Hoffmeyer 1996).

\section{The experienced semiosphere}

Eliminativist philosophers have claimed that human experiences are epiphenomenal on brain activity, illusions, so to say, that strangely accompany our dealings with the world. We do not run because we are afraid of the attacking bear - to use the classical example - rather our fear is a registration of our own escape behavior. This understanding does of course save the materialist ontology from having to accord direct causal effects to mental phenomena, but it also leaves the phenomenological world as a complete mystery. What is the good of it? Why is it there? Since scientific theories themselves can only serve us to the extent that we can experience them, i.e. understand them, this eliminativist view of things is in fact quite paradoxical: only because we have a psychic life can we develop theories according to which psychic life is not for real.

To get rid of this absurd logic in a non-dualistic way we need to understand experienced life as both real and based on bodily existence. There is - biosemiotics will claim - nothing mysterious about the phenomenal world, for it is deeply embedded in bodily semiotics. Because human beings are highly organized unities of some 50,000 billions of cells, each of which have a limited but real semiotic competence, the mystery of the experienced world has to find its solution by considering the kind of semiotic skills such unities might 
develop. An evolutionary account of experience does require us to accept that at least some big-brained animals do posses a rudimentary kind of an experienced Umwelt in the sense experienced Umwelten are known to ourselves. The main question then will be to identify the type of needs such an experienced Umwelt might satisfy better than any instinctive or reflex-based behavior would do. An additional question of course is how this ability for experiencing is rooted in the emotional brain. We shall suggest some possible answers to the first of these questions, whereas the latter question will only be slightly touched upon.

The key to our problem is to be found in the already mentioned holistic "egotism" of animals. We saw that the evolution of a holistic organismic intentionality (in the sense so clearly absent from Siamese twins in salamanders) required us to think of natural selection as being elaborated inside the constraints of situated ecosemiotic interaction patterns (called ecosemiotic motif's in Hoffmeyer 1997). Thus, for instance, mammalian species in general seem to master significantly more sophisticated ecosemiotic motifs than do reptilian species. The Swedish ethologist Sverre Sjölander has pointed out that while for instance a dog need not have a full picture of the hare all the time for hunting it efficiently, a snake will stop hunting its prey whenever it disappears from view (Sjölander 1995). The snake may well go on searching for the prey at the spot, where it disappeared, but it will not calculate the eventual path the prey may have taken. The dog on the other hand will proceed away, guided by an anticipation of where the hare would be expected to turn up next. "Thus it seems as if the representation or construct of the hare is 'running' in the internal world in a way corresponding to the actual hare in the actual world" writes Sjölander, so that "the sense organs are just used to correct the representational happenings and not to create them" (Sjölander 1995: 3). In the snake, on the contrary, hunting appears to be guided by a succession of quite independent sense modalities. Thus, striking of prey is governed by sight (or temperature sense organs); location of the struck prey is detected by smell, and the swallowing procedure is governed by touch. This lack of true intermodality in the snake makes it "hard to imagine that the snake can harbor some form of a concept of a mouse in its brain" (Sjölander 1995: 5). The snake apparently can not integrate its sense modalities to form a central construct. 
This does not necessarily mean that snakes are totally deprived of an experienced world, but if indeed they have experiences, these must be lacking in inner coherence and would certainly be very different from our own kinds of experiences. Snakes have survived well on Earth for a long time, and to the best of my knowledge are still doing fine in their distinctive niches, but it is indeed striking, as Sjölander observes, that the fanciful catastrophic schemes for explaining how reptiles were superseded by birds and animals presently adopted by most scholars do not account for why the reptiles did not just repopulate their old niches after the dust had settled down again in the aftermath of the catastrophe. Here the ability of birds and mammals to produce central internal constructs of their Umwelten does indeed offer an attractive alternative explanation for the fact that these taxonomic groups did ultimately become the successful groups among vertebrates.

A moving animal in a moving world is confronted with a perpetual need for making split-second choices of behavior. Such choices evidently will serve survival the best if they are based on some kind of anticipatory calculation which integrates inner body parameters such as emotional states, fatigue, hunger, memory into a range of external parameters as registered by the sense organs. As long as the animal is small and has a survival strategy based on simple activity schemes in a predictable range of challenges, these behavioral decisions may well be accounted for in terms of instinctive patterns of sensomotoric reflex circles. Such a direct connection between a stimulus and a corresponding behavioral act is perhaps what takes place in the snake, so that in its Umwelt there is indeed no mouse, but only things to be searched for, things to be stroked, and things for swallowing, whereas for animals dealing with more complex patterns of challenges a direct coupling of stimulus and behavior is no longer sufficiently flexible. Instead, the brained body as an holistic intentional unity must now make decisions based on split-second evaluations of unforeseeable events. Judging from the efficiency of modern computer programming in producing virtual realities, there is probably no a priori reason why brains could not have solved this problem by a sophisticated elaboration of the reflex circuit principle. But while computers are designed to obey strategies decided by the programmer, organisms had to develop designs obeying their own interests, and this is where the computer analogy may mislead us. Organisms must integrate their 
life project into their calculatory potential. The body as flesh and blood therefore from the very beginning has to be part of the anticipatory and inventive brain models. We shall suggest this is the reason why nature invented the trick of producing an experienced holistic virtual reality, an internal icon more or less isomorphic in its properties with those parts of the real world that the animal could not safely ignore. ${ }^{3}$ The exciting (threatening, attractive etc.) aspects of the outer world in this way became internalized as inner threats, attractions etc., thereby assuring the necessary immediate emotional bias in all choices of action. The hard problem was not just to calculate the path of action but to make sure this path of action was the most relevant given the life project of the animal, and this is where the emotional apparatus enters the scene. The iconic inner experience works as a holistic marker focusing the enormous diversity of calculations upon a single path of action.

As Maxine Sheets-Johnstone has repeatedly pointed out, movement is not just doing, it is also always sensing (Sheets-Johnstone 1990; 1998). Millions of proprioceptive sense cells are distributed in our muscles throughout the body, perpetually measuring the tension between cell layers and sending messages thereabout to the brain. Brain models governing motoric activity anticipate the eventual signals they receive from proprioceptive organs, perpetually calibrating their dynamics to the delayed response from tissues. Organisms model their own bodies as much as they model the outer world - or as Sheets-Johnstone puts it: "creatures know themselves" (SheetsJohnstone 1998: 285) — and they do so while their tissues are bathed in endocrine secretions, constantly updating their emotional response parameters to the experienced icons running in the brain. SheetsJohnstone indeed suggests a natural history for proprioception tracing this kind of self-knowledge in movement right back to the chemotaxis in bacterial cells depending on flagellar movement. And since consciousness is as Merleau-Ponty has explained (Merleau-Ponty 2002: 160) not primarily an "I think that" but an "I can", proprioception might be understood, as Sheets-Johnstone observes, as a kind of "corporeal consciousness":

John Deely pointed me to this very apt formulation of the Uexküllian conception of neutrality in the Umwelt (originally suggested by Thomas Sebeok). 
Corporeal consciousness thus evolved from its beginnings in tactility into kinesthesia, into a direct sensitivity to movement through internally mediated systems of corporeal awareness, In effect, through all the intricate and changing pathways of descent with modification, know thyself has remained a consistent biological built-in; a kinetic corporeal consciousness informs a diversity of animate forms. (Sheets-Johnstone 1998: 286)

It seems plausible to suppose that experiential life is not an either-or phenomenon, but a thing that comes in many grades and in a multitude of versions depending on the ecosemiotic motifs, which are most vital to the particular species. Furthermore, just like we ourselves are not aware most of the time of things around us, or even our own presence, other creatures' experienced life may also possibly appear only in distinct glimpses of "enlightened" activity, and very likely in most species only little connection occurs between such glimpses of awareness, even when they happen more or less contemporaneously. We also know that we can do lots of complicated kinds of work without even being aware of it, awareness being perhaps instead directed to chatting with friends or looking at TV. This shows us that experience is not necessary for doing routine work, and you can even sometimes get away with routine talking when your mind is on other matters (though usually this is immediately perceived and considered highly impolite). But the very fact that routine work can be efficiently effectuated without us being aware of it immediately poses the problem of why we are aware of anything at all. And obviously, the answer is that the experienced world is a tool for solving non-routine problems, or, in general, for dealing with events which could not be foreseen. And a certain capacity to deal with the unforeseen is probably a help for most organisms capable of moving, which in multicellular organisms implies the presence of a neurosemiotic control system. Lacking movement as part of their survival tool kit, plants most likely never developed experiential worlds, whereas a graded series of such worlds may well occur as glimpses of awareness throughout the animal kingdom. But only in mammals and birds do these phenomenal worlds operate on constructed virtual items behaving very much like things and creatures outside of the head. And only in the human animal are these constructs understood as constructs, i.e. as different from the things and animals they are supposed to represent in the real world. 
Our virtual worlds are tools for survival and as such they remain constrained by the very same rules that are operative in the real world. One should not therefore believe that our virtual worlds, the Umwelten, are all we have access to, and that the real world, the Ding an Sich, is unapproachable. On the contrary, the semiotics of corporeal life in any creature - ourselves included - does take part in the dance of ecosemiotic motifs, the local Planmässigkeit, which has been framing the evolutionary processes and has formed the particular form of the Umwelt of each species. The Umwelt must serve to guide the animal's activity in the semiotic niche, i.e. the world of cues around the animal (or species) which the animal must necessarily interpret wisely in order to enjoy life. The semiosphere, as I use the term, i.e. the totality of actual or potential cues in the world, is thus to be understood as an externalistic counterpart to the totality of Umwelten. Together they form, in the term of Jakob von Uexküll, an unending set of 'contrapuntal duets'.

\section{References}

Brooks, Daniel R.; Collier, John; Maurer, Brian A.; Smith, Jonathan D. H.; Wiley, Edward O. 1989. Entropy and information in evolving biological systems. Biology and Philosophy 4(4): 407-432.

Buss, Leo W. 1987. The Evolution of Individuality. Princeton: Princeton University Press.

Depew, David J.; Weber, Bruce H. 1995. Darwinism Evolving: Systems Dynamics and the Genealogy of Natural Selection. Cambridge: Bradford/The MIT Press.

Hamburger, Viktor 1988. The Heritage of Experimental Embryology: Hans Spemann and the Organizer. Oxford: Oxford University Press.

Hoffmeyer, Jesper 1996. Signs of Meaning in the Universe. Bloomington: Indiana University Press.

- 1997. Biosemiotics: Towards a new synthesis in biology. European Journal for Semiotic Studies 9(2): 355-376.

- 1998. Surfaces inside surfaces: On the origin of agency and life. Cybernetics and Human Knowing 5(1): 33-42.

- 2000. Code-duality and the epistemic cut. Annals of the New York Academy of Sciences 901: 175-186.

- 2001a. Life and reference. BioSystems 60(1/3): 123-130.

- 2001b. Seeing virtuality in nature. Semiotica 134(1/4): 381-398.

Hoffmeyer, Jesper; Emmeche, Claus 1991. Code-duality and the semiotics of nature. In: Anderson, Myrdene; Merrell, Floyd (eds.), On Semiotic Modeling. New York: Mouton de Gruyter, 117-166. 
Kauffman, Stuart A. 1993. Origins of Order: Self-Organization and Selection in Evolution. New York: Oxford University Press.

- 1995. At Home in the Universe. New York: Oxford University Press.

- 2000. Investigations. Oxford: Oxford University Press.

Merleau-Ponty, M. 1995 [1968]. La Nature. Notes. Cours du Collège de France. Paris: Editions du Seuil.

— 2002 [1945]. Phenomenology of Perception. London: Routledge.

Neumann, John von 1966. Theory of Self-Reproducing Automata. Urbana: University of Illinois Press.

Pattee, Howard H. 1977. Dynamic and linguistic modes of complex systems. International Journal for General Systems 3: 259-266.

Prigogine, Ilya 1980. From Being to Becoming. San Fransisco: Freeman.

Salthe, Stanley 1993. Development and Evolution: Complexity and Change in Biology. Cambridge: MIT Press.

Santaella Braga, Lucia 1999. A new causality for the understanding of the living. Semiotica 127(1/4): 497-519.

Sebeok, Thomas A. 1979. The Sign and Its Masters. Austin: University of Texas Press.

Sheets-Johnstone, Maxine 1990. The Roots of Thinking. Philadelphia: Temple University Press.

- 1998. Consciousness: A natural history. Journal of Consciousness Studies 5(3): 260-294.

Short, T. L. 2002. Darwin's concept of final cause: Neither new nor trivial. Biology and Philosophy 17: 323-340.

Sjölander, Sverre 1995. Some cognitive breakthroughs in the evolution of cognition and consciousness and their impact on the biology of language. Evolution and Cognition 1(1): 3-11.

Sober, Elliott 1984. The Nature of Selection. Chicago: The University of Chicago Press. (Cit. via Short 2002)

Spemann, Hans 1943. Forschung und Leben. Stuttgart: Engelhorn. (Cit. via Hamburger 1988)

Stjernfelt, Frederik 2001. A natural symphony? To what extent is Uexküll's Bedutungslehre actual for the semiotics of our time? Semiotica 134(1/4): 79102.

Uexküll, Jakob von 1992 [1957, 1934]. A stroll through the worlds of animals and men: A picture book of invisible worlds. Semiotica 89(4): 319-391.

Uexküll, Thure von 1992a. Preface. Semiotica 89(4): 277.

- 1992b. Introduction: The sign theory of Jakob von Uexküll. Semiotica 89(4): 279-315.

Weber, Bruce H. 1998. Emergence of life and biological selection from the perspective of complex systems dynamics. In: Vijver, Gertrudis Van de; Salthe, Stanley N.; Delpos, Manuela (eds.), Evolutionary Systems: Biological and Epistemological Perspectives on Selection and Self-Organization. Dordrecht: Kluwer Academic Publishers, 59-66. 


\section{«Плановость» Юкскюлла}

В противовес преобладающему позитивисткому воззрению на природу как на нечто свободное от значения, Якоб фон Юкскюлл утверждал, что определенная “плановость" в природе имеет место. Увы, данное утверждение можно понимать и как взгляд, в соответствии с которым сама органическая эволюция не является созидающим процессом, а постепенным (но все же величественным) выявлением строительного плана самой Природы. Подобная идея может вновь способствовать утверждению в центре биологической теории детерминизма, что радикально противоречило бы биосемиотическому взгляду. Одним из источников как биосемиотики, так и космологической философии Пирса является мысль, что неопределенность первична, что “привыкание” или интерпретация являются реальными процессами природы, и поэтому вера в предначертанность необоснована. В статье утверждается, что “плановость" Юкскюлла можно сопоставить с современным недетерминистским пониманием. В определенном смысле умвельты животных действительно развивались согласно природной “плановости", но это такой план, который беспрерывно держит жизнь в оковах определенных стратегических выборов и одновременно разнообразит измерения условий этих выборов, т.е., согласно Стюарту Кауффманну, “сопутствующую возможность".

\section{Uexkülli 'plaanipärasus'}

Otsese vastandina valdavale positivistlikule looduse mõistele — loodusele, mis on mõtteta ning tähendusest vabastatud — väitis Jakob von Uexküll, et teatud plaanipärasus on looduses toimiv. Seda võib paraku võtta kui vaadet, mille kohaselt orgaaniline evolutsioon ise pole loov protsess, vaid on järkjärguline (ometi küll majesteetlik) Looduse enese ehitusliku plaani väljakoorumine. Selline idee võib kaasa aidata determinismi taaspüstitamisele bioloogilise teooria keskmes, mis räägiks tõsiselt vastu biosemiootika vaatele. Nii biosemiootika kui Peirce'i kosmoloogilise filosoofia lähtekohti on, et määramatus on esmane, et "harjumine" ehk interpreteerimine on reaalsed protsessid looduses, mistõttu usk ettemääratusse on põhjendamatu. Väidetakse, et Uexkülli plaanipärasus on kokkusobitatav tänapäevase mittedeterministliku arusaamaga. Teatud mõttes on loomade omailmad tõepoolest arenenud vastavalt looduslikule 
plaanipärasusele, kuid see on plaan, mis lakkamatult hoiab elu teatud strateegiliste valikute kütkes ja ühtaegu mitmekesistab nende valikute tegemise tingimuste mõõtmelisust, s.t. "külgnevat võimalikkust", Stuart Kauffmani järgi. 